\title{
Cardiac sarcoidosis, a rare disease?
}

Irina Strâmbu ${ }^{1,2,3, *}$, Livia Luculescu³ ${ }^{3}$ Mihai Alexe ${ }^{3}$, Sebastian Onciul ${ }^{4}$

${ }^{1}$ MD, PhD, Marius Nasta Institute of Pneumophtysiology, Pulmonology I Dept., Sos. Viilor 90, Sector 5, Bucharest, Romania.

2University of Medicine and Pharmacy, "Carol Davila", Pulmonology V Dept., Bucharest, Romania

IInstitute of Pneumophthysiology, "Marius Nasta", Bucharest, Romania

Abstract

${ }^{4}$ Clinical Emergency Hospital, Cardiology Dept., Bucharest, Romania

\section{English:}

We present the case of a male patient, 34 years old, non-smoker, presenting repeatedly in the past 2 years in emergency and cardiology departments for episodes of palpitation accompanied by faitness. One of the electrocardiograms recorded in emergency department captures bigeminated ventricular premature heartbeats. A cardiac magnetic resonance imaging (MRI) examination in May 2019 showed increased thickness of left ventricle during systole and contrast enhancement in the middle of cardiac wall at the base of the heart, considered initially as hypertrophic non-obstructive cardiomyopathy. The reinterpretation of MRI suggested that the changes were typical for cardiac sarcoidosis. Investigations performed later showed increased angiotensin-converting enzyme (ACE); thoracic computed tomography (CT) scan showed nodules and micronodules bilateral in upper lobes with moderate mediastinal lymph node enlargement and bronchoalveolar lavage (BAL) showed lymphocytic alveolitis with normal CD4/CD8 ratio, normal lung function with normal diffusing capacity. Even without biopsy, but based on CT scan, BAL and ACE, the patient was diagnosed as sarcoidosis with lung and cardiac involvement and was started on oral corticosteroids (methylprednisolone $32 \mathrm{mg} / \mathrm{day}$ ). The diagnosis of cardiac involvement as initial presentation of sarcoidosis is difficult, due to limited knowledge about the disease among cardiologists and radiologists. Though, a recurrent arrhythmia, potentially severe, in a young patient in the absence of an alternative cause, should raise the suspicion for sarcoidosis with cardiac involvement, with a potential severe outcome in the absence of treatment.

Keywords

cardiac sarcoidosis $\bullet$ cardiac magnetic resonance $\bullet$ bronchoalveolar lavage $・$ EBUS

\section{Sarcoidoza cardiacă - O boală rară?}

Rezumat

\section{Romanian:}

Prezentăm cazul unui pacient de sex masculin de 34 de ani, nefumător, care s-a prezentat în ultimii 2 ani repetat la serviciul de urgență și ulterior de cardiologie pentru accese de palpitații însoțite de stare prelipotimică. Una din electrocardiogramele în urgență surprinde extrasistole ventriculare bigeminate. Examen RM cardiac efectuat în mai 2019 evidențiază creșterea grosimii miocardului ventriculului stg în sistolă și priză de contrast medioparietală bazal, interpretate inițial ca o cardiomiopatie hipertrofică neobstructivă cu arii de dezorganizare fibrilară. Ulterior, reinterpretarea RM a sugerat modificări tipice de sarcoidoză cardiacă. Investigațiile efectuate ulterior au evidențiat angiotensinconvertază serică crescută, examenul CT toracic evidențiază noduli și micronoduli pulmonari cu distribuție peribronhovasculară bilateral în lobii superiori, cu adenopatii mediastinale moderate, lavajul bronho-alveolar evidențiază alveolită limfocitară cu raport CD4/CD8 normal, funcția pulmonară normală, fără tulburări de difuziune.

Chiar în absența biopsiei, s-a pus diagnosticul de sarcoidoză cu afectare cardiacă și pulmonară, pe baza CT, LBA și ACS. S-a inițiat corticoterapie sistemică cu metilprednisolon $32 \mathrm{mg}$ pe zi.

Diagnosticul afectării cardiace ca manifestare inițială a sarcoidozei este dificil, datorită cunoașterii limitate a bolii în rândul cardiologilor și radiologilor. Totuși, o tulburare de ritm recurentă, cu potențial sever, la un pacient tânăr, în absența altei explicații, trebuie să ridice suspiciunea de sarcoidoză cu afectare cardiacă, a cărei evoluție poate fi severă în lipsa tratamentului.

Cuvinte-cheie

sarcoidoză cardiacă • rezonanță magnetică cardiacă • lavaj bronho-alveolar • EBUS

${ }^{*}$ Corresponding author: Irina Strâmbu

E-mail: istrambu@yahoo.com

Ә Open Access. (C) 2019 Strâmbu et al., published by Sciendo

(B) BY-NC-ND This work is licensed under the Creative Commons Attribution-NonCommercial-NoDerivs 4.0 License. 


\section{Introduction}

Sarcoidosis is a systemic granulomatosis of unknown cause, affecting mostly the mediastinal lymph nodes and lungs, but almost any organ, such as the liver, spleen, eyes, heart, nervous system, kidneys, extra-thoracic lymph nodes and so on, can be involved (1).

The disease can appear in a single episode, with about twothirds of the cases resolving spontaneously, or it can persist as a chronic condition, with relapses occurring at intervals of several months or years.

Currently, numerous questions about sarcoidosis, such as what is the aetiology of the disease, is there a genetic predisposition, what are the risk factors for a chronic evolution, what is the reason why different organs are involved in different subjects, and so on, remain unanswered (2).

Overall, the disease can have a very polymorphic presentation, which makes the diagnosis difficult sometimes. Extra-respiratory involvement is especially difficult to identify, if this is the initial presentation, in the absence of a previous diagnosis of sarcoidosis.

\section{Case presentation}

We present the case of a male patient, 34 years old, never smoker, complaining in the past 2 years of recurrent episodes of palpitations, accompanied by a pre-lipotimic state. He presented repeatedly in the emergency department, where a ventricular tachyarrhythmia was objectified on the electrocardiogram (ECG) (Figure 1). Heart ultrasound performed during these episodes showed normal ventricular function with no other changes. He was typically receiving intravenous lidocaine, with remission of the arrhythmia, was recommended $24 \mathrm{~h}$ recording of the ECG and was referred to an arrhythmia specialist.

The patient had repeated cardiology check-ups and was recommended several anti-arrhythmic drugs (bisoprolol, sotalol and propafenone) but the episodes continued to appear. A 24-h recording of the ECG was performed, which showed very frequent premature ventricular beats, with homogeneous morphology mimicking a right heart bundle block (Figure 2).

In January 2019, the patient has performed a cardiac magnetic resonance (CMR) with gadolinium enhancement. The initial description made by the radiologist referred to late phase contrast uptake at the base of the septum with a fibrillar disorganisation, interpreted as non-obstructive hypertrophic cardiomyopathy with areas of fibrillar disorganisation. The ventricular function was normal, with an ejection fraction (EF) estimated at $65 \%$.

It was 8 months later, in September 2019, when the same CMR was presented for a second opinion. This time the images were reviewed by a cardiologist with specific training in CMR. The report described normal cardiac dimensions and ventricular function, and a hypertrophy at the base of interventricular septum. In T2 focal oedema was visible at the base of the septum, and homogeneous late uptake of gadolinium in the granuloma was present (Figure 3). Overall, the changes were considered as typical for cardiac sarcoidosis, and the patient was recommended to perform supplemental tests for confirmation.

The thoracic computed tomography (CT) scan showed multiple micronodules spread bilaterally with upper predominance

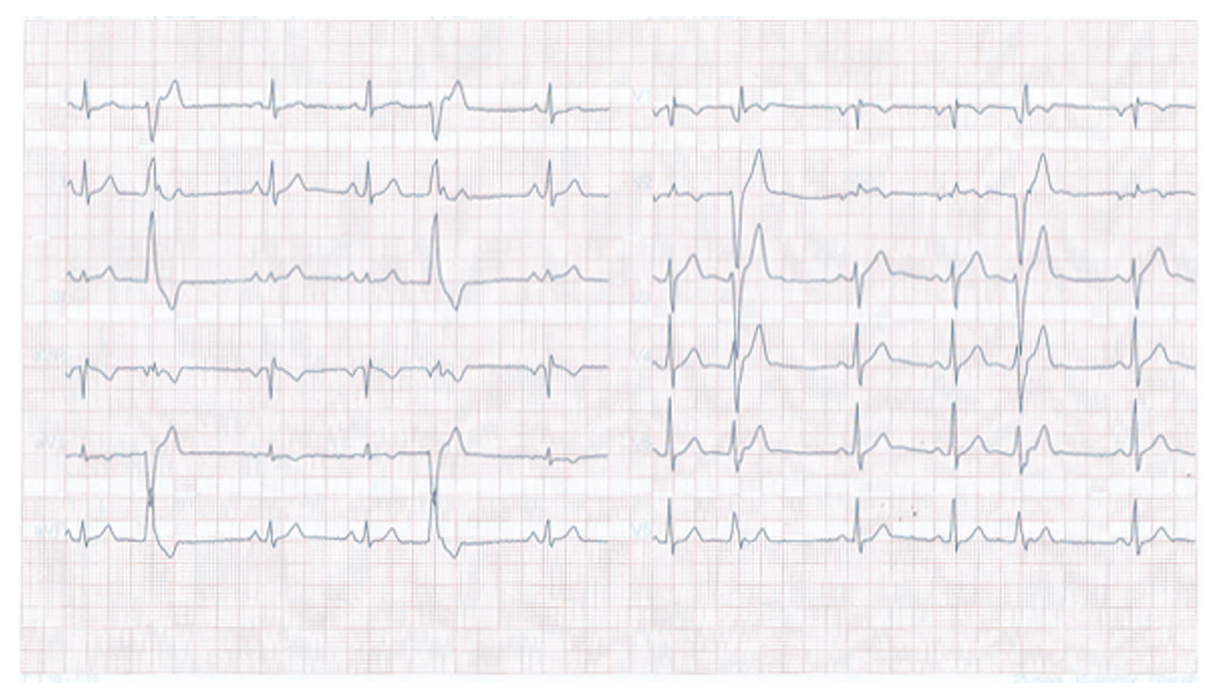

Figure 1. ECG recorded during an emergency presentation, showing frequent premature ventricular beats. 


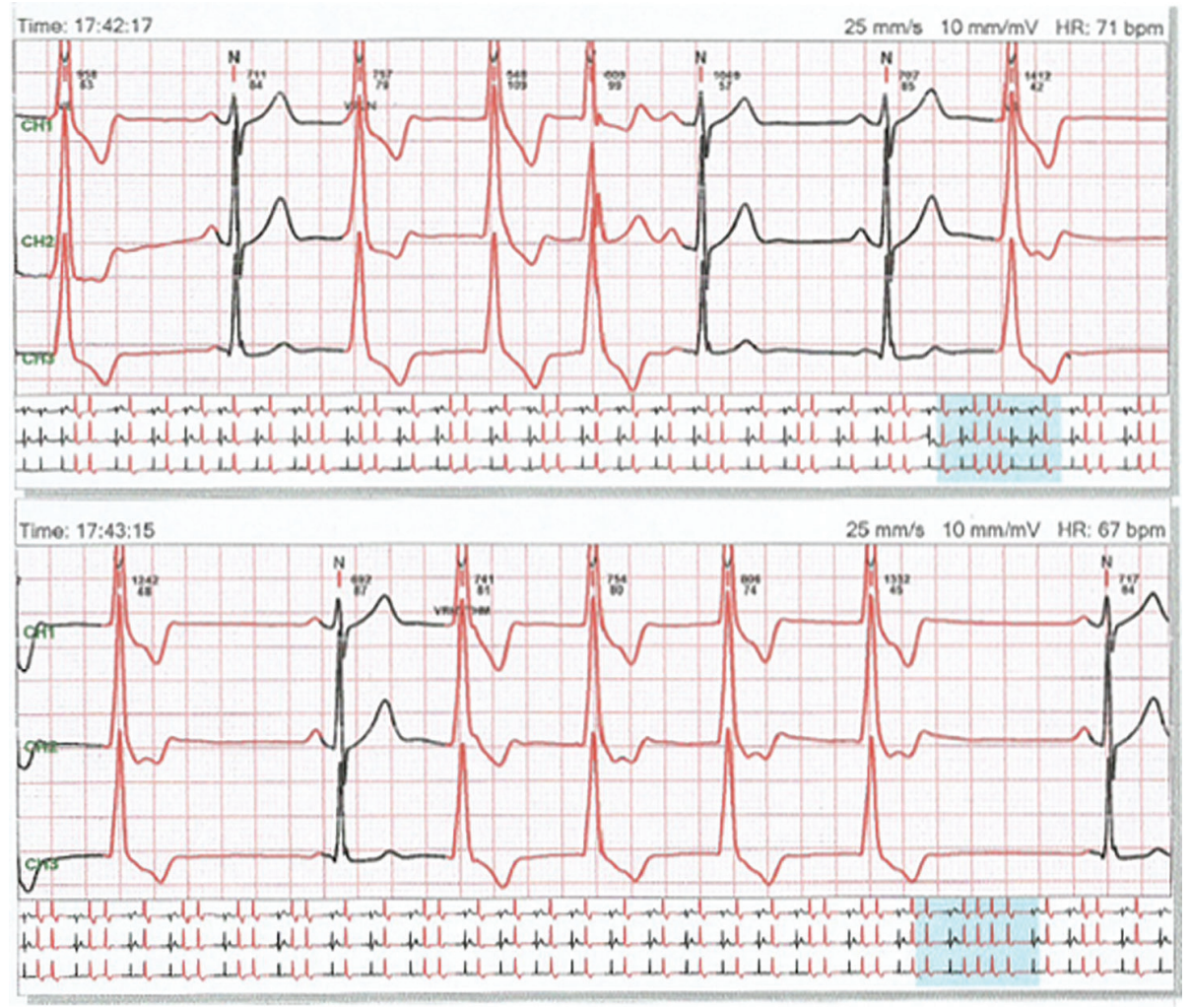

Figure 2. A 24-h recording of ECG showing frequent premature ventricular beats with unique morphology, mimicking a right bundle branch block.

and peribroncho-vascular distribution, as well as moderate enlargement of mediastinal lymph nodes (Figure 4).

A bronchoscopy was performed, with no noticeable changes in the bronchi. The bronchoalveolar lavage (BAL) showed a lymphocytic alveolitis, with $34.4 \%$ lymphocytes in the BAL fluid. The CD4/CD8 ratio was normal (2.6). A transbronchial needle aspiration guided by ultrasound endobronchial ultrasound (EBUS) was performed, aiming the enlarged lymph nodes visible on the CT scan. The cytological result was not against sarcoidosis anyway without a clear histological confirmation: rare lymphocytes and macrophages and very few giant cells. Angiotensin-converting enzyme (ACE) was measured in the blood, showing an increased value, threefold the normal upper limit.

Lung function tests showed normal lung volumes and a normal diffusing capacity for carbon monoxide, in concordance with the absence of respiratory symptoms.

Even in the absence of a biopsy proving the presence of typical granulomas, the patient was diagnosed with sarcoidosis involving the lungs, the mediastinal lymph nodes and the heart, based on the CT and BAL findings, ventricular tachyarrhythmia with typical CMR changes and increased ACE.

More recently, the patient started to complain of slight but persistent dizziness, so a cerebral magnetic resonance (MR) was recommended to check for potential brain involvement.
In October 2019, the patient started corticosteroid treatment with methylprednisolone $32 \mathrm{mg} /$ day. After about 2 weeks he reported that the dizziness improved, and no other palpitation episodes were noted. Anyway, these symptoms were previously occurring after longer periods of time, so, at the time of evaluation, it was too early to state that there is a therapeutic response on the cardiac involvement. The patient was scheduled for follow-up and made a new appointment with the arrhythmia specialist.

\section{Discussion}

Cardiac sarcoidosis is considered to be one of the most severe organ involvements of the disease, with potential for sudden death due to ventricular arrhythmia, and for decreased life expectancy in case of reduced EF (3).

Symptomatic cardiac involvement was noted in about $5 \%$ of patients with confirmed sarcoidosis. However, imaging studies showed cardiac changes in about $30 \%$ of sarcoidosis patients (4).

The diagnosis of cardiac sarcoidosis can be extremely difficult if this is the first presentation of sarcoidosis.

As in any form of sarcoidosis, histological diagnosis performed by endomyocardial biopsy is the golden standard. Anyway, it was showed that endomyocardial biopsy has an 

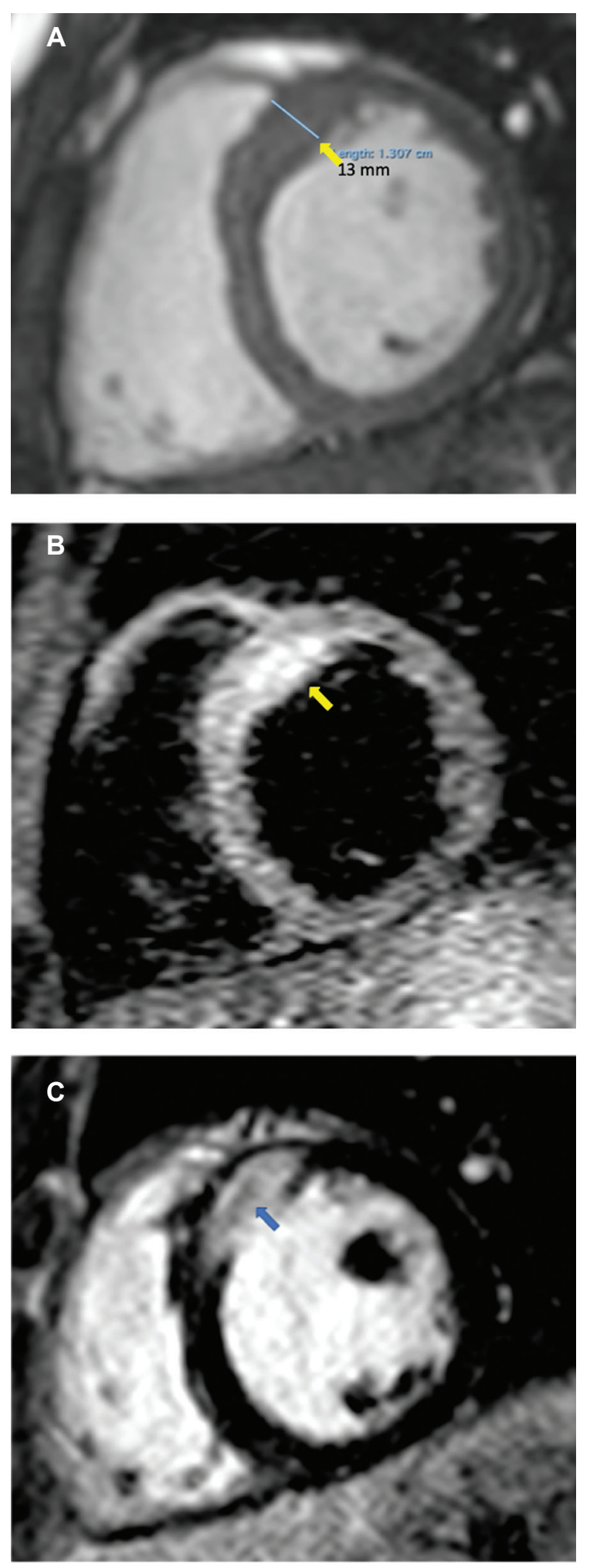

Figure 3. CMR. (A) Hypertrophy localised at the base of the septum. (B) T2 focal oedema at the base of the septum. (C) Late gadolinium enhancement: homogeneous late uptake of gadolinium in the granuloma. excellent specificity, but a low sensitivity (20-30\%). This can be improved to $50-55 \%$ by anatomo-electric mapping (5).

The WASOG criteria for the diagnosis of cardiac sarcoidosis, classified according to the organ assessment instrument developed by this society, include (6):

- Highly probable: biopsy with granulomatous inflammation of no alternate cause

- Probable:

- Treatment responsive cardiomyopathy

- Atrio-ventricular (AV) block

- Reduced left ventricle EF in the absence of other clinical risk factors

- Spontaneous or inducible sustained ventricular tachyarrhythmia with no other risk factor

- Mobitz type II or third degree heart block

- Patchy uptake on dedicated cardiac PET

- Delayed enhancement on CMR

- Positive gallium uptake

- Defect on perfusion scintigraphy or single photon emission computed tomography (SPECT) scan

- T2 prolongation on CMR

- Possible:

- Reduced LVEF in the presence of other risk factors (e.g. systemic hypertension, diabetes mellitus)

- Atrial dysrhythmias

- No consensus:

- Frequent ectopy (>5\% QRS)

- Bundle branch block

- Impaired right ventricle function with a normal pulmonary vascular resistance

- Fragmented QRS or pathologic Q waves in $\geq 2$ anatomically contiguous leads

- At least one abnormal signal averaged ECG domain

- Interstitial fibrosis or monocyte infiltration

At clinical presentation, patients typically complain of palpitations and sometimes syncope (5). The ECG can reveal AV blocks or arrhythmia, especially ventricular. Less frequent, patients may present bundle branch blocks, or the ultrasound may reveal pericardial fluid accumulation, valvular abnormalities or ventricular dysfunction.

ECG can be normal outside the episodes and can miss the diagnosis.

Unfortunately, it was shown that cardiac ultrasound does not provide consistent hints for the suspicion of the disease (7).

The diagnosis relies very much on modern imaging techniques. CMR with gadolinium enhancement can prove the presence of granulomas in the structure of interventricular septum or in the ventricular walls, especially at the base of the heart. CMR can reveal regional motility abnormalities of the wall, late uptake of gadolinium or regional increase of 

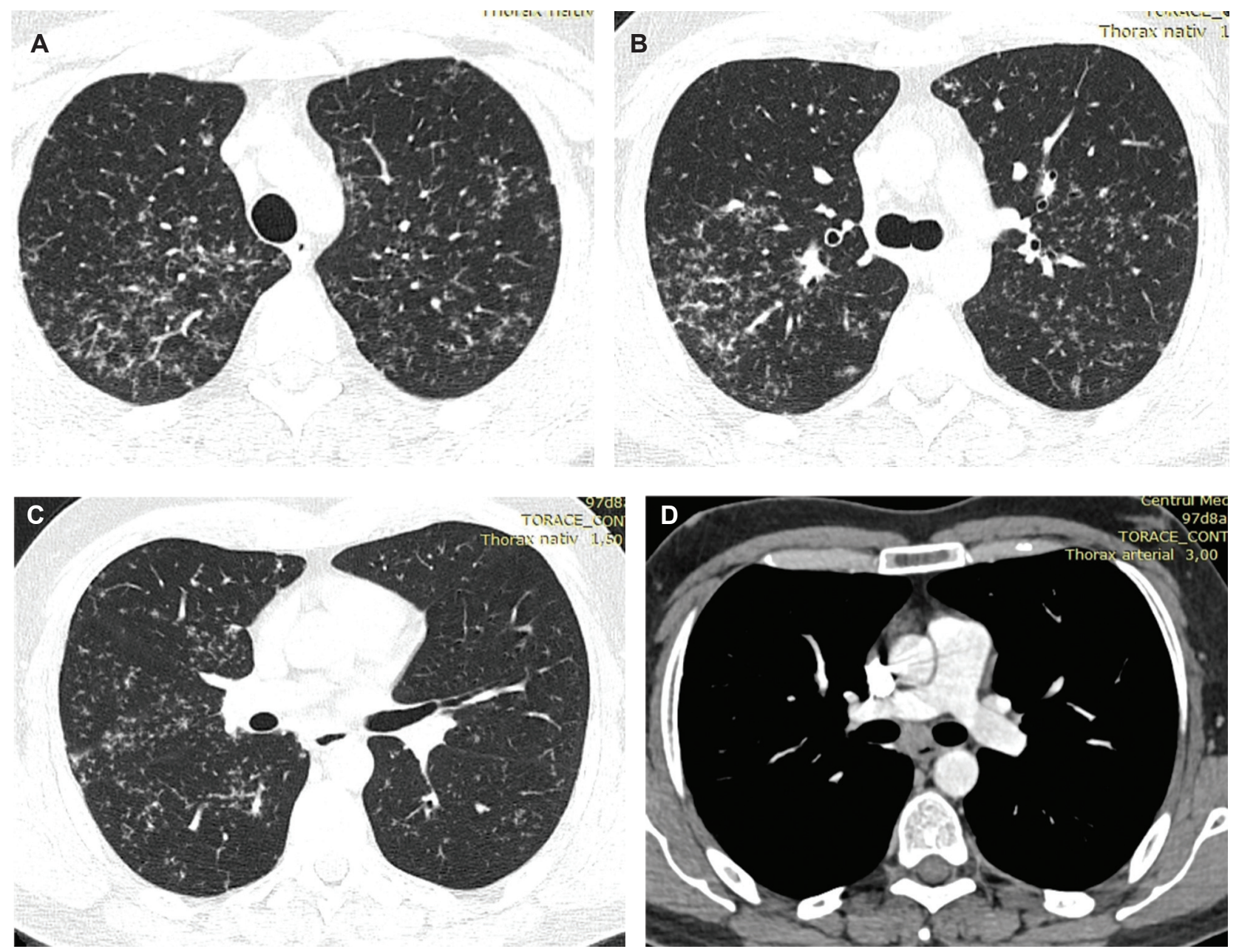

Figure 4. High-resolution CT of the lungs: multiple bilateral micronodules predominant in the upper lobes, increased infracarinal lymph nodes.

the signal in T2. CMR has a sensibility of $76 \%$ and a specificity of $92 \%(8)$.

Fluorodeoxyglucose positron emission tomography (FDGPET) shows a focal increased uptake of the glucose in the granulomas, with a sensibility of $89 \%$ and a specificity of $78 \%$. Like any sarcoidosis diagnosis, the presence of epithelioid giant cell granuloma without necrosis is the golden standard for diagnosis (9). Anyway, it is preferable to confirm the diagnosis by sampling a more accessible site, outside the heart. FDG-PET can be very useful for localising all the organ involvements of the disease and for choosing the more appropriate site for a biopsy (10).

In our patient, a mediastinal lymph node biopsy was attempted using a TBNA-EBUS technique, but with a disappointing result. Another option would have been a lung biopsy performed by a peripheral transbronchial forceps biopsy or cryobiopsy (the latter is not available in our centre), or a surgical lung biopsy. The patient did not agree with either option.
Cardiac sarcoidosis is among the disease involvements considered as high risk and is mandatory to treat (11). Oral corticosteroids are the first line of treatment, without having a consensus regarding the dosage and the duration of treatment (12). Several cohorts mentioned starting doses between 20 and $60 \mathrm{mg} / \mathrm{day}$, and durations of treatment between 3 months and 5 years (13). It was shown that a dose higher than $40 \mathrm{mg} /$ day prednisone does not improve survival. It was also shown by CMR that granulomas in the heart muscle can completely resorb with treatment, without leaving scars.

Other immunosuppressive treatments, such as methotrexate, azathioprine or infliximab, in stand-alone treatments or corticosteroid-sparing regimens, were proposed. It was shown that the combination therapy corticosteroids-methotrexate can have better results on the EF than corticosteroids alone (14). Anti-arrhythmic drugs are mandatory, recommended in collaboration with the cardiologist. 
Several electrophysiological techniques, such as ablation therapy, placement of pacemakers, can be useful for preventing the recurrence of arrhythmia, especially in case of AV block or severe ventricular dysrhythmias (15).

The prognosis is influenced by the delay in the onset of the treatment and the presence of reduced EF. The response on reduced EF is better if the treatment is started earlier in the course of the disease (13).

Factors for a worse prognosis are high BNP levels, high troponin I level, age over 46 years, a low left ventricle EF, late uptake of gadolinium at the base of the septum on CMR (due to the risk of AV block) and perfusion defects on FDG-PET $(16,17)$.

Screening for cardiac sarcoidosis should be performed in any patient diagnosed with sarcoidosis. The reason why cardiac sarcoidosis seems to be a rare disease is probably due mostly to the lack of suspicion of the heart involvement. A medical history of palpitations should be actively sought for during the initial interview, and also at follow-up. Unfortunately, there is no well-established method for the screening of cardiac involvement in cardiac sarcoidosis, as ECG and cardiac ultrasound do not give valuable hints, while CMR and FDG-PET are expensive and with limited availability (4).

In our patient, in the absence of a previous diagnosis of sarcoidosis, the CMR changes were initially misinterpreted, leading to a delay in the diagnosis and initiation of treatment.

\section{Conclusion}

Cardiac sarcoidosis can be a challenging diagnosis, especially in patients not having other manifestations of the disease. Cardiac involvement should be actively looked-for in all patients diagnosed with sarcoidosis, due to its high risk for a severe outcome in the absence of treatment.

\section{References}

1. Sharma OP, Defining sarcoidosis. In: Mitchell D, Wells A, Spiro S, Moller D, (eds.) Sarcoidosis. Boca Raton: CRC Press; 2012.

2. Thillai $M$, Wickremasinghe $M$, Lalvani $A$, Moller $D$, Mitchell $D$. Etiology. In: Mitchell D, Wells A, Spiro S, Moller D. (eds.) Sarcoidosis. Boca Raton: CRC Press; 2012. p.27-40.

3. Lyne JC, Savage HO, Oldershaw PJ. The heart. In: Mitchell D, Wells A, Spiro S, Moller D. (eds.) Sarcoidosis. Boca Raton: CRC Press; 2012.

4. Ribeiro Neto ML, Jellis CL, Joyce E, Callahan TD, Hachamovitch R, Culver DA, Update in cardiac sarcoidosis. Annals ATS 16, 11, 2019, doi:10.1513/AnnalsATS.201902-119CME.
5. Ardehali H, Howard DL, Hariri A, Qasim A, Hare JM, Baughman $\mathrm{KL}$, et al. A positive endomyocardial biopsy result for sarcoid is associated with poor prognosis in patients with initially unexplained cardiomyopathy. American Heart Journal. 2005;150: 459-463.

6. Judson MA, Costabel U, Drent M, Wells A, Maier L, Koth L, et al. The WASOG sarcoidosis organ assessment instrument: un update of a previous clinical tool. Sarcoidosis Vasculitis and Diffuse Lung Diseases. 2014;31; 19-27.

7. Kandolin R, Lehtonen J, Airaksinen J, Vihinen T, Miettinen $\mathrm{H}$, Ylitalo $\mathrm{K}$, et al. Cardiac sarcoidosis: epidemiology, characteristics, and outcome over 25 years in a nationwide study. Circulation. 2015;131: 624-632.

8. Schulz-Menger J, Wassmuth R, Abdel-Aty H, Siegel I, Franke A, Dietz $R$, et al. Patterns of myocardial inflammation and scarring in sarcoidosis as assessed by cardiovascular magnetic resonance. Heart. 2006;92: 399-400.

9. Blankstein R, Osborne M, Naya M, Waller A, Kim CK, Murthy VL, et al. Cardiac positron emission tomography enhances prognostic assessments of patients with suspected cardiac sarcoidosis. Journal of the American College of Cardiology. 2014;63: 329-336.

10. Sobic-Saranovic D, Grozdic I, Videnovic-Ivanov J, VucinicMihailovic V, Artiko V, Saranovic D, et al. The utility of 18F-FDG $\mathrm{PET} / \mathrm{CT}$ for diagnosis and adjustment of therapy in patients with active chronic sarcoidosis. Journal of Nuclear Medicine. 2012;53: 1543-1549.

11. Baughman RP, Judson MA, Wells A. The indication for the treatment of sarcoidosis: wells law. Sarcoidosis Vasculitis and Diffuse Lung Diseases. 2017;34: 280-282. doi:10.36141/svdld. v34i4.6954.

12. Chapelon-Abric $C$, de Zuttere $D$, Duhaut $P$, Veyssier $P$, Wechsler $B$, Huong DL, et al. Cardiac sarcoidosis: a retrospective study of 41 cases. Medicine (Baltimore). 2004;83: 315-334.

13. Sadek MM, Yung D, Birnie DH, Beanlands RS, Nery PB. Corticosteroid therapy for cardiac sarcoidosis: a systematic review. Canadian Journal of Cardiology. 2013;29: 1034-1041.

14. Nagai S, Yokomatsu $T$, Tanizawa $K$, Ikezoe $K$, Handa $T$, Ito $Y$, et al. Treatment with methotrexate and low-dose corticosteroids in sarcoidosis patients with cardiac lesions. Internal Medicine. 2014;53: 427-433.

15. Birnie DH, Sauer WH, Bogun F, Cooper JM, Culver DA, Duvernoy CS, et al. HRS expert consensus statement on the diagnosis and management of arrhythmias associated with cardiac sarcoidosis. Heart Rhythms. 2014;11: 1305-1323.

16. KikoT, YoshihisaA, KannoY, YokokawaT,Abe S, Miyata-TatsumiM, et al. A multiple biomarker approach in patients with cardiac sarcoidosis. International Heart Journal. 2018;59: 996-1001.

17. Zhou Y, Lower EE, Li HP, Costea A, Attari M, Baughman RP. Cardiac sarcoidosis: the impact of age and implanted devices on survival. Chest. 2017;151: 139-148. 